\title{
An Introduction to New Historicism
}

\author{
Xiaotang Lyu \\ Faculty of Foreign Languages, Huaiyin Institute of Technology, Huaian, Jiangsu 223001, China \\ Email:27544162@qq.com
}

\begin{abstract}
New Historicism is a literary practice which came into being in the early 1980s. The most distinctive concepts and procedures of this literary analysis and interpretation are assimilated from various poststructural theorists. Stephen Greenblatt inaugurated the popularity of the label "New Historicism" in his introduction to a special issue of Genre, Vol 15(1982), and the representatives of New Historicism are Stephen Greenblatt, Louis A. Montrose and so on.
\end{abstract}

Key words: New Historicism, Stephen Jay Greenblatt, Louis A. Montrose, Hayden White

\section{INTRODUCTION}

One branch of historiography is the historicism. There were two contradictory approaches to literary history throughout the 19th century. One presented it as "a series of isolated monuments and achievements of individual genius" while the other was historicist who saw literary history as part of a large cultural history." [1] And some historicists, who are influenced by the Hegelian idealism and the evolutionary naturalism of Herbert Spencer, study literature in the context of social, political and cultural history and place history as the background of the literary texts. However the new historicists conceive that "the literary text is situated within the institutions, social practices and discourses that constitute the overall culture of a particular time and space, and that the literary text interacts as both a product and a producer of cultural energies and codes."[2] Not dealing with a text in isolation from its historical context, new historicists pay more attention to the historical and cultural context of the literary text. This is not the simple return to the old historicism, because the former scholars had taken the social and intellectual history as the background of the literary works and they had tried to divide history into different periods in tableaux. But the New Historicism has viewed literature as the reflection of the worldview of a period. From the perspective of the new historicists, history is not merely the background of literature any more. Literary texts not only represent the conclusion of a cultural conversation in one historical period but also participate in that conversation. Literary texts are agents as well as effects of cultural change and are parts of the documents which compose the history.

\section{THE THEORETICAL ORIGIN OF NEW HISTORICISM}

New Historicism appeared as a mode of literary practice since the early 1980s. Stephen Jay Greenblatt inaugurated the popularity of the label "New Historicism" in his introduction to a special issue of Genre, Vol 15(1982). Just as every literary criticism absorbing the elites of the former criticism, New Historicism is mainly the result of concepts and ideas of literary analysis and interpretation that have been assimilated from various poststructural theorists, especially Louis Althusser's Marxist ideology, Michel Foucault's discourse and power, the central concept in deconstructive criticism and Clifford Geertz's anthropology.

Louis Althusser, the French philosopher and the outstanding marxist, created the symptomatic reading method which influence Stephen Jay Greenblatt a lot. Symptom is a medical term originally and Sigmund Freud uses it to describe the inconscient psychological forces in psychological analysis. Usually these psychological forces are depressed and they can only go into the consciousness when the depression become flexible or disappear at random. So symptom is used to refer to the idees inconscients and Louis Althusser develops it into the symptomatic reading method. And the symptomatic reading is related to the surdetermination theory which emphasizes that we should not understand this world in dualism. Except for the economic basis and the ideology, we should also take the multiple conflicts of the texts and the ideology which originates from politics, economics, religion and 
other fields into consideration. The social ideology is full of contradictions and conflicts and all the texts are in the same situation so we cannot interpret them with the accordant theory. Louis Althusser shows us that the assumed unified interpretation methods prevent readers from understanding the complexity and the richness of the texts and the texts are full of the unknown both to the author and the reader. And we need another interpretation method to get insight of the contradictory, complicated, multifarious and disordered contents which we cannot master from the general reading. Louis Althusser's symptomatic reading inspires the new historists to explore the deep meaning between the lines from different perspectives and it supplies the method to interpret the texts for New Historicism.

Michel Foucault is a French philosopher and his discourse and power theory has profound influence on New Historicism which take history as discontinuous and narrative. Michel Foucault holds the view that the history is in discontinuity and his discourse theory is used to support his ideas. In the social practice, discourse is language which refers to the statement and representation of the social and cultural elements. Michel Foucault's discourse mainly refers to knowledge which is a single set of structured statement and the discourse concept is continuous and diverse. Discourse is the application of language in the social and cultural practice and it is a system of the verbal language and the written and unwritten text symbols. The discourse is related to the power which is negative and repressive. According to Foucault, the power not only produces things and discourse but also induces pleasure and forms of knowledge. Through the discourse the concepts, ideas and the structures of institutions can be attributes to the circulation and exercise of power. The power is never monolithic and the power relations always imply multiple sites not only of power but also of resistance. Foucault's flexible conception of power relations may accommodate local instances of a subversion that is produced for containment. Subversion and containment is a significant concept in new historicism.

Clifford Geertz's symbolic anthropology influenced the new historists of the 1970s and 1980s. The typical literary comments of new hisrorists take use of the Geertzian model of thick description in the initial deployment of an exemplary anecdote as a strategy of cultural and historical estrangement. For Clifford Geertz, culture is the medium of semiosis, a set of control mechanisms,such as plans, recipes,rules and instructions, for the governing of behavior and a system of codes regulates social life by governing the production of those ensembles of conventions, practices and artifacts to which the word culture is often loosely applied. Geertz interprets culture as an exemplary and eminently literary method for narrating culture in action and culture lived in the performances and narratives of individual and collective human beings. And this kind of rhetorically self-conscious ethnographic practice is the thick description. The thick description can also be described as interpretive narration and it seizes on an event, performance and other practices.

\section{NEW HISTORICISM}

In 1960s and 1970s, the poststructuralist intellectual revolution challenged the old historicism on several aspects and established a new set of assumptions: Firstly, history is always "narrated" and the past is always in the form of "representations" so the first sense is untenable; Secondly , there is no single "history", only discontinuous and contradictory "histories"; Thirdly, the past is not something which confronts us as if it were a physical object, but is something we construct from already written texts of all kinds of which we construe in line with our particular historical concerns; Fourthly, "history" is always a matter of telling a story about the past, using other texts as our intertexts and literary works should be regarded as texts among other texts. These academic ideas are very different from the old historicists who hold the views that history is not so much textual as more simply "a series of empirically verifiable events".[3] And the new historicists argue that any knowledge of the past is necessarily mediated by the current authorities and history is textual in many respects. New Historists pay more attention to the conflict and contradiction in suspense, and they take the marginal events and figures the same way with the mainstream. Instead of praising the existent aesthetics, new historists focus more on the exploring of the formation process of the ideology and the material basis.

To some extent the new historicism is not a single methodology but a kind of literary criticism practice. As a literary criticism, New Historicism is difficult to give the definition and just as H. Aram Vesser says :"New Historicists combat empty formalism by pulling historical considerations to the center stage of literary analysis"[4]. The representatives of New Historicism are Stephen Greenblatt, Louis Adrian Montrose and so on and they have resisted identifying their approaches with a single methodology.

Stephen Greenblatt, professor of Harvard University and an excellent Renaissance scholar, is the leader of new historicism and his study inspires other early new historicists, such as Louis A. Montrose, Walter Benn Michaels, and Catherine Gallagher. In fact, Stephen Greenblatt had used the other term, cultural poetics, for New Historicism but the academic circle was used to New Historicism. Some of the earlier important New Historicist appeared in the journal, Representations, which Greenbaltt helped to found when he taught at the University of California, Berkeley. His subversion and containment mode has been accepted commonly in the field of Shakespeare and Renaissance. And his anecdotism which analyze. the texts from both literature 
and non-literary material, from the mainstream and the marginal is widely adopted by the new historists and is used by the New Historicism as thick description.

Stephen Greenblatt also borrows the term - social energy, circulation, exchange and negotiation from economics and takes use of them to analyze the literary works of Renaissance.

Louis A. Montrose described the new historicism as "a reciprocal concern with the historicity of texts and the textuality of history." The historicity of texts shows us the social and material embedding of all kinds of writing and the historical, social and material embedding of all kinds of reading. And the textuality of history has two aspects of connotations. On one hand, "we can't get access to a full and authentic past, to a lived material existence which is not mediated by the surviving textual traces of the society in question" and the surviving textual traces are preserved and effaced to some extent.[5] On the other hand, the scholars who profess the humanities are based on their descriptive and interpretive texts used those preserved traces to compose the documents selectively. According to Louis A. Montrose, history is not a set of fixed, objective facts, but the conceived and interpreted texts. Furthermore, all the texts are conceived as discourse which consist of the verbal formations of an era.

Although Hayden White never admits that he is a New Historicist, his academic thoughts of history are similar with the theoretician of New Historicism. His systematic research on metahistory theory contributes to the solid theoretical foundation of New Historicism. He contributes his whole life to the study on the relationship between literature and history. Hayden White notes that "historical work is a verbal structure in the form of a narrative prose discourse."[6]. He used metonymy,metaphor, synecdoche and irony to interpret the historiography of the nineteenth century, which shows that history, just like literature, takes use of the rhetoric in the emplotment too. The objective description of the historical event is impossible since the rhetoric not only describes but also interprets the events. Chinese scholar Zhu Gang points out that Hayden White's theory comes down in one continuous line with "the poststructuralist reflections of the historical narration." [7] According to Hayden White, history is a narrative account and it is unavoidably figurative, allegorical, and fictive. History is represented to us and it is impossible to access the authentic past due to the rhetoric narration. And he holds the view that not only the relationship of literary texts and their cultural and historical context is intertextual, the literary texts and the former texts are also intertextuality.

Since Hayden White challenged the authority of history as a scientific course, the postmodernists paid more attention to history-fiction subject. In A Poetics of Postmodernism, Linda Hutcheon holds the view that both history and fiction are discourse in postmodern writing, and that the meaning and shape are constructed as historical facts according to the rules of the narrative system. She reveals the fictive nature of history and asserts that history and fiction are both identified as linguistic constructs and they are highly conventionalized in their narrative forms.

Although New Historicism is not a unified practice, all the new historists usually have the same literary criticizing mode. They, at first, find out an anecdote from the ignored resources, such as part of the history event, a poem, the pictures and the architectural design, and then explore the deep insight and meaning of them to relate them with their research. Finally, the new historists focus on the connections between the custom, cultural situation and the ideology of the literary works in the composing period and the texts to touch the real traces of the event. And new historists' literary practice also has the functions of constructing the histories to uncover the false face of the grand historical narration, which is called counter-histories.

\section{CONCLUSION}

Different from other literary criticism, New Historicism pays more attention to literary practice than theoretical construction, and different representatives have different proposals. But the new historists still have the consensus that "the core of new historicism centrally concerns with the relationship between history and text, the commonality between historical and literary texts."[8] H. A. Vesser has made a commonly-accepted summary of new historicists' theoretical assumptions in his The New Historicism:

1. Every expressive act (including literature) is embedded in a network of material practices;

2. Every act of unmasking, critique, and opposition uses the tools it condemns and risks falling prey to the practice it exposes;

3. Literary and non-literary "texts" circulate inseparably;

4. No discourse, imaginative or archival, gives access to unchanging truths nor expresses inalterable human nature;

5. A critical method and language adequate to describe culture under capitalism participate in the economy they describe.

The above analysis of New Historicism shows us that there is no unified and continuous "History" but only the discontinuous and contradictory "histories". Since history is full of textuality, the past can never be available to us in authentic and pure form. And new historicists' interpretation of history was, to some extent, integrated into the postmodern literature. 
Although new historicism has been widely accepted and practiced in literary criticism, it still has its shortcomings, such as the roughly description of the historical context and the selective choice of the literary texts. Different literary criticism can supply different perspectives to understand and interpret the literary works, and New Historicism also gives us a perspective to analyze the texts from the more grand way.

\section{ACKNOWLEDGMENT}

This work was supported by The General Project of Philosophy and Social Science Research in Colleges and Universities in Jiangsu Province(2019SJA1651).

\section{REFERENCES}

[1] R. Selden, A Reader's Guide to Contemporary Literary Theory, Foreign Language Teaching and Research Press, 2004.

[2] M. H. Abrams, A Glossary of Literary Terms, Foreign Language Teaching and Research Press, 2004.
[3] A. Bennett, R. Nicholas, An Introduction to Literature, Criticism and Theory, Routledge, 2016.

[4] H. A. Veeser, The New Historicism, Routledge, 1989.

[5] S. Greenblatt, G. Gunn, Redrawing the Boundaries: the transformation of English and American literary studies. The Modern Language Association of America, 1992.

[6] H. White, Metahistory: The Historical Imagination in Nineteenth-Century Europe. The Johns Hopkins University Press, 1973.

[7] Zhu G., Twentieth Century Criticism. Peking University Press, 2006.

[8] J. McGann, Historical Studies and Literary Criticism. The University of Wisconsin Press, 1985. 